\title{
Amylin in the Periphery
}

\author{
Peter J. Wookey ${ }^{1, *}$, Loredanna Xuereb ${ }^{1}$, Christos Tikellis ${ }^{2}$, \\ and Mark E. Cooper ${ }^{2}$ \\ ${ }^{1}$ Department of Medicine, University of Melbourne, Austin and Repatriation \\ Medical Centre, Repatriation Campus, Heidelberg West, Victoria and ${ }^{2}$ The \\ Baker Heart Research Institute, Prahan, Victoria, Australia \\ E-mail: pwookey@unimelb.edu.au; Ixuereb@austin.unimelb.edu.au; chris.tikellis@baker.edu.au; \\ mark.cooper@baker.edu.au
}

Received April 9, 2002; Revised June 7, 2002; Accepted June 26, 2002; Published March 24, 2003.

Amylin (islet amyloid polypeptide) is a peptide synthesized principally in the $\beta$ cells of the pancreatic islets together with insulin and has actions as a hormone, growth factor, and modifier of behavior. As a hormone, amylin acts to modify gastric motility, renal resorption, and has metabolic actions. It is postulated that the principal function of amylin as a hormone is the activation of physiological processes associated with feeding. As a growth factor, amylin acts on bone cells, renal proximal tubular cells, and islet $\beta$-cells. Amylin has important targets in the brain that mediate its actions in the modification of behavior, including thirst and satiety. In man, amylin can form islet amyloid deposits, an event linked to the reduction of $\beta$-cell mass and loss of signal-secretion coupling. Recent evidence has defined a new role for monomeric amylin as a growth factor and regulator of $\beta$-cell mass that is postulated to be a key factor in pathophysiological processes that result in overt diabetes.

KEY WORDS: amylin, islet amyloid polypeptide, hormone, growth factor, behavioral modifier, pancreatic islets, amyloid deposition, $\beta$-cell dysfunction, diabetes

DOMAINS: gene expression, protein folding, clinical chemistry, experimental medicine, molecular medicine, molecular pharmacology, cell death, development, growth and growth factors, hormone signaling, metabolic disease, neural networks, bone biology, endocrinology, nephrology

\section{INTRODUCTION}

This mini-review is based on contemporary research that investigates the physiological roles of amylin and the pathophysiological consequences of variations in expression. Readers are directed to previous reviews for further discussion of prior research $[1,2,3,4,5,6]$.

The contemporary view of many peptides present in the periphery includes the ability to elicit acute responses in target cells as hormones, to act as growth factors in particular contexts, and to 
alter behavior through actions in the brain. Amylin, discovered about 15 years ago[7,8], displays all these characteristics. The key actions of amylin as a hormone involved in gut motility, putative renal resorption, and metabolic outcomes, and as a peptide regulating thirst and satiety, provide the rationale that one of amylin's primary physiological roles is the activation of systems associated with feeding[4,9].

There are some peculiar features of amylin that have suggested a crucial role in the etiology and development of diabetes and associated complications. These features include the major site of biosynthesis being in the $\beta$-cells of the pancreatic islets[8], which is also the principal site for the biosynthesis of insulin. Amylin from humans[7,8] and other animals, including cats[8,10], has the potential to form amyloid deposits in the islets, thereby contributing to $\beta$-cell destruction, resulting in overt diabetes[11]. Indeed, the description of amyloid in the pancreas in association with diabetes is 100 years old, although its composition was only delineated 15 years ago[7,8]. The potential role of monomeric amylin as a growth factor is also explored in this article, as a mechanism influencing $\beta$-cell mass.

One of the major obstacles in the delineation of the involvement of amylin and amyloid deposition in these pathophysiological phenomena, and in the further exploration of amylin biology in general, is the paucity of nonpeptide antagonists and agonists, which one would predict would be forthcoming with increased knowledge of the primary amylin receptor(s).

\section{SITES OF AMYLIN BIOSYNTHESIS}

The major site of amylin biosynthesis lies in the pancreatic islet $\beta$-cells, but secondary sites are found in the gastrointestinal tract[12,13], dorsal root ganglia[14,15,16], and in the developing kidney[18], where expression appears tightly controlled (discussed below[18]). In diabetic states little is known about expression from these secondary sites and any significance that this might have for the etiology of the disease and associated complications.

\section{HUMAN AMYLIN, NATURAL GENE MUTATIONS, AND DIABETES}

The composition of amyloid deposits and how this influences $\beta$-cell function are among the key issues in the understanding of the pathogenesis of noninsulin-dependent diabetes melitus (NIDDM), a disorder for which there is increasing awareness of the role of $\beta$-cell dysfunction and atrophy[11]. Related to these issues is the mechanism(s) of amyloidogenesis, which in some cases is deleterious and in others apparently better tolerated by islet cells. This may be reflected in the fact that although $57 \%[19]$ to $>90 \%[20]$ of NIDDM subjects display amyloid deposits in the islets, many nondiabetic individuals also show pancreatic amyloid deposition $[8,19]$.

One of the early events in the pathogenesis of diabetes is considered to be an alteration in the signal-secretion coupling that finally results in the constitutive secretion of $\beta$-cell hormones and prohormones[21]. Furthermore, amylin has been found to modulate and/or inhibit insulin secretion in human studies[22]. A further question in relation to these putative changes in $\beta$-cell responses might involve the efficacy of amylin as a growth factor for $\beta$-cells (discussed below) and any role that reduced $\beta$-cell mass might have in the events leading to overt diabetes.

Investigations using biophysical techniques have identified sequences of human proamylin that may contribute to the processes of amyloid formation including phenylalanine-23[23] and sequences in the amino and carboxy terminal regions[24,25,26]. A molecular-recognition and self-assembly domain of IAPP/amylin has been identified in recent experiments[27]. Deamination of asparagines in this region dramatically affects aggregation of amyloidogenic peptides[28]. The finding that $2.6 \%$ of the Japanese[29,30] NIDDM population carried a mutation 
that resulted in a serine-20-> glycine conversion, compared to $0.8 \%$ of the total population (also in Hong Kong[31]) suggests that specific amino acids within the amylin molecule play a role in the pathogenesis of NIDDM[32]. A heparin-binding domain that may play a role in amyloidogenesis has also recently been described[33]. The prohormone convertase processing site is also located in this domain[34]. Such observations may ultimately lead to the identification of new factors that influence amyloidogenesis and are useful in the treatment of type II diabetes.

\section{TRANSGENIC MOUSE MODELS THAT EXPRESS HUMAN AMYLIN}

A useful experimental model to study the amyloidogenic effects of human amylin and variants is the transgenic mouse that expresses human amylin. Eight research groups have reported the results of studies using this model[35,36,37,38,39,40,41,42]. One general theme, i.e., that the amount of secretion of human amylin determines the level of amyloidosis, was reiterated in a recent paper in which amounts of dietary fat[43] induced islet amyloidosis and impaired insulin secretion. These models are also potentially important to test candidate drugs effective in the inhibition and reversal of amyloidosis[44]. These studies varied in their conclusions but it is clear that there are still unknown factors important in the progression to overt diabetes following deposition of amyloid proteins. It is likely that the toxicity of particular amyloid deposits is dependent also on the state of the $\beta$-cells, and that human $\beta$-cells may behave differently from their mouse counterparts. Furthermore, the identification of some upstream mutations[45], which are linked to a propensity to develop diabetes, may corroborate the general view that the amount of amylin secreted is also a contributing factor. Some important upstream elements include Pax-4 regulatory elements that mediate expression of amylin and insulin[46]. Pax-4-deficient mice do not develop $\beta$ - and $\partial$-cells, and die shortly after birth from diabetes.

\section{AMYLIN AS A HORMONE}

Early studies highlighted the hyperglycaemic effects of amylin compared to glucagon[47], although the physiological mechanisms have not been clarified. Over a longer period of time, rats infused into the third ventricle with an antagonist of amylin ate more food and accumulated body fat without significant changes in body weight[48]. Thus the amylin concentration of the cerebrospinal fluid may contribute to long-term energy balance. Such a mechanism may also play a role in the glucagonostatic effect of amylin that is thought to be extrapancreatic in origin[49]. A 4-h infusion of amylin also significantly altered liver and muscle triglycerides without changes to steady-state serum levels. It is not clear what is the pathway of action and whether it is local or mediated through the CNS as discussed above[50]. Furthermore and in contrast to the results of antagonist infusion in the ventricle, subcutaneous administration of amylin in mice over a longer period increased bone mass and fat[51]. The possible role of amylin in lipid metabolism has been further explored in metabolic models infused with an amylin peptide antagonist[52].

In the periphery, amylin has important functions in proximal tubules of the kidney where it stimulates sodium/water resorption[53]. To explain its renal actions, high-affinity amylin binding sites have been identified on the proximal tubules[54]. Furthermore, intracellular, amylin immunoreactive vesicles have been detected within these tubules (data not shown).

The actions of amylin in the renal cortex are thought to include the maintenance of the polarity of proximal epithelial cells[4]. These functions, together with sustained activation of amylin receptors[55], are considered important in the pathogenesis of hypertension[56] and may be linked to renal complications associated with diabetes. 


\section{AMYLIN IN THE MODIFICATION OF BEHAVIOR}

Although this brief review concentrates on "amylin in the periphery", some research relevant to its actions in the CNS and modifications of behavior are important to discuss for a more complete picture of the overall physiological role(s), particularly related to feeding.

The known actions of amylin as a hormone capable of behavioral modifications are equally diverse by increasing satiety[9,57], thirst[58], memory[59,60], and motor activity by interfering with central dopaminergic transmission[61]. Furthermore, effects via the PNS have been reported including inhibition of gastric emptying[13,62,63] and reduced nociception in the amylin genedeletion mouse[64].

Two main regions of the circumventricular organs in the brain mediate peripheral variations in amylin levels. These include effects on drinking and feeding behavior via receptors in the subfornical organ $[58,65,66]$ and area postrema $[67,68]$, respectively.

The pathways of enhanced neural activity following amylin activation in the CNS are not yet defined but are likely to involve the histaminergic system[69], in particular H1 receptors. Evidence has also been presented implicating part of the dopaminergic system[70].

The nucleus accumbens, in which high-affinity amylin binding sites have been found in high density[71,72], may be one internal region processing these peripheral signals[73]. Furthermore, neuropeptide $\mathrm{Y}$-induced feeding at the level of the hypothalamus is markedly attenuated by infusion of amylin[74]. The definition of the CNS pathways at the level of the neuron may be possible by identifying c-Fos activation, cGMP formation[67] and electrophysiological studies.

\section{AMYLIN AS A GROWTH FACTOR}

Amylin mRNA transcripts (unpublished data) and protein[13,75] are expressed early in the latter half of gestation starting at embryo day 11/12 in the rat pancreatic diverticulum where amylin is expressed by P-cells[76]. These observations suggest that any function associated with the early fetal expression of this peptide is likely to involve a role for amylin as a growth factor.

\section{Osteoblasts and Osteoclast Differentiation}

Research into the potential effects of amylin on bone density followed the observation that osteopenia was common in diabetic subjects[77,78,79,80]. Indeed, this potential effect of amylin was among one of the earliest physiological effects described following its discovery. It was demonstrated subsequently that amylin acted as a growth factor in bone for the proliferation of osteoblasts[81,82] and more recently in osteoclast differentiation[83].

\section{Renal Cortex}

Amylin is also a potent proliferation factor both during the development of proximal tubules[18] and in the proliferation of adult epithelial cells[53]. The relevance of this action of amylin as a growth factor in vivo is further emphasized by the finding that amylin is expressed in the proximal tubules of the developing kidney. This occurs prior to vascularization of the rat kidney with peak levels of amylin mRNA at postnatal day 5 (PN5), some 200-fold higher than found in adult kidney (Fig. 1). This event is tightly regulated, a characteristic of the precise events that regulate growth factors during organogenesis. The identification of the factors that control this tight regulation of amylin expression may prove to be important later in pathogenic processes 


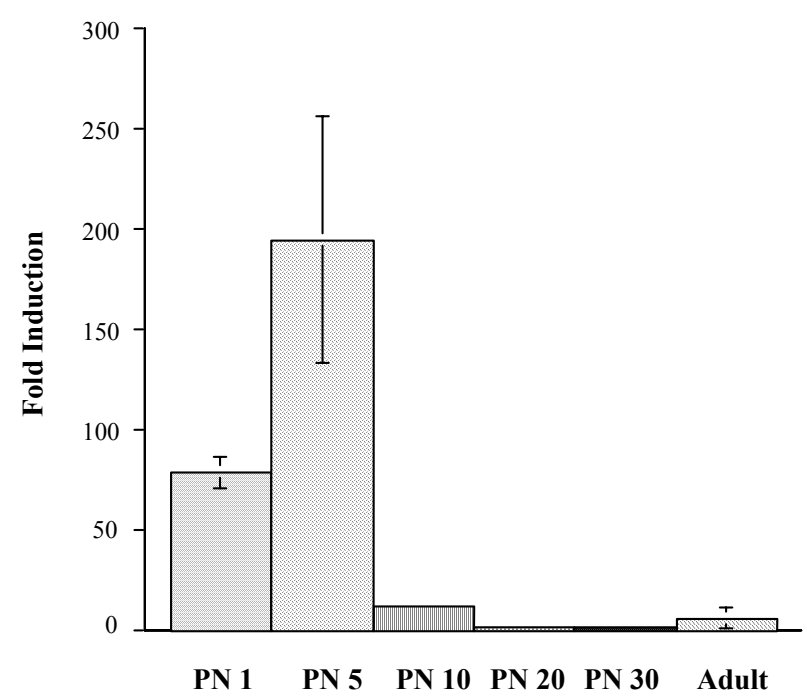

FIGURE 1. Real time PCR determinations[17] on developing postnatal (PN day 1-30) rat kidneys to quantify levels of amylin mRNA relative to adult kidney.

such as the development of renal complications associated with diabetes and renal regeneration following other insults.

The analysis of renal development in the amylin gene-deletion (AGD) mouse model[64,84,85] has provided further evidence for the role of amylin as a renal growth factor. First, the profile of levels of amylin mRNA found in the wildtype (WT) mouse kidney (unpublished) is similar to data shown in Fig. 1. By contrast, in AGD mice, amylin mRNA biosynthesis is absent (by real time PCR) indicating that this renal transcript is normally encoded by a single amylin gene. This is corroborated by our finding that the full cDNA sequence of amylin mRNA from rat kidney, as determined using Rapid Amplification of cDNA Ends (RACE), corresponds to the sequence of the mRNA transcript expressed in the islets.

Second, this has detectable consequences as seen in the enlargement of inter-tubular spaces (proximal tubular dropout or a deficiency in the mass of convoluted tubules) in the AGD vs. WT developing kidney and the extension of the proximal epithelial lining into Bowmans capsule which is significantly reduced in adult AGD mice[86].

The physiological consequences of this anatomical abnormality are as yet unclear but it should be noted that these AGD mice clear glucose at a faster rate compared to WT[84,87], which may be related to renal functions in these mice.

\section{Pancreatic Islets}

It has been known for some time that amyloid can induce $\beta$-cell death[88]. However a new aspect of $\beta$-cell biology has recently been described, which may have significance for the maintenance of $\beta$-cell mass. Monomeric amylin has been found to be a growth factor for isolated fetal $\beta$ cells[89]. This follows previous descriptions of its effect on cells involved in bone metabolism[81,83,90] and primary cultures of renal proximal tubular epithelial cells[18,53]. Furthermore, amylin may potentiate the effects of other growth factors in inducing proliferation of adult $\beta$-cells (E. Karlsson, personal communication).

In this context, we have analyzed the pancreata of adult WT $(n=3)$ vs. AGD $(n=3)$ mice and shown that islet $\beta$-cell mass was greatly reduced in the latter. The analyses and volume determinations of pancreata and islets were derived from three-dimensional reconstructions aided 
by computer imaging techniques using serial sections stained to detect insulin (Fig. 2: upper panels, WT; lower panels, AGD).
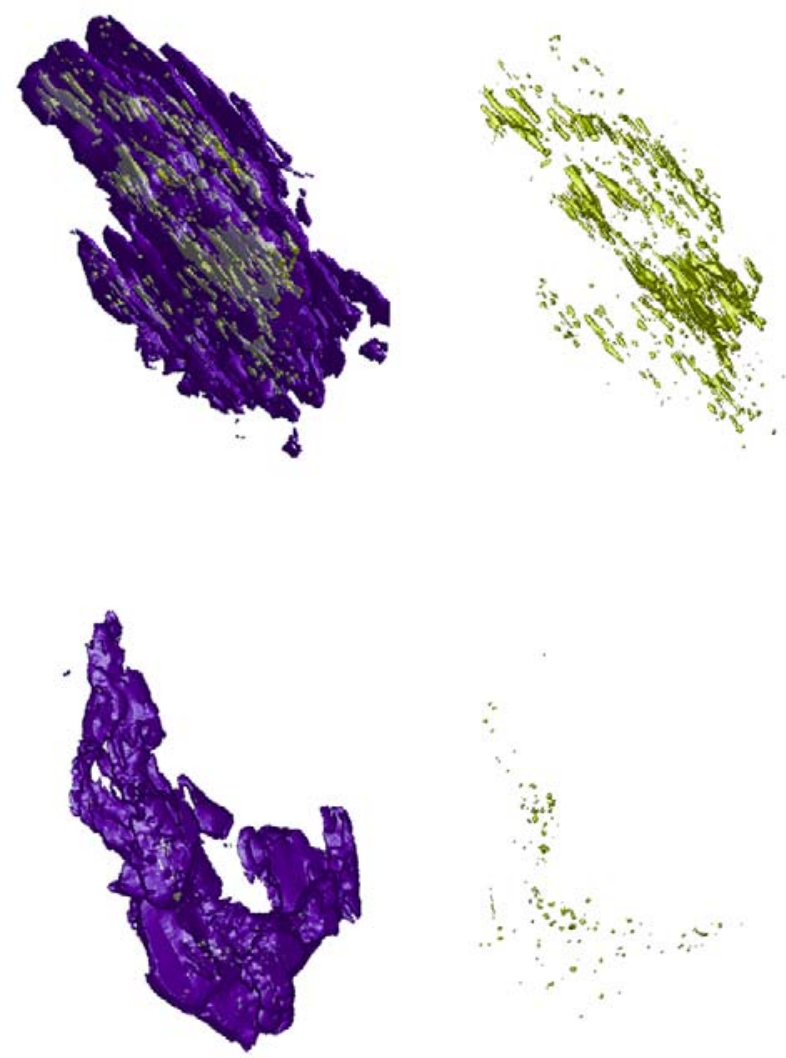

FIGURE 2. Representations of three-dimensional reconstructions of total pancreatic tissue (left side) and islet tissue (right side) from WT (top row) and AGD (bottom row) adult mice (see text for results of quantification).

From these data, the total volume of each pancreas and the internal islet volume were calculated (the ratio of total pancreatic volume to islet volume; WT, 51.7; AGD, 2024). The total islet volume of the AGD pancreas was found to be about $1 / 40^{\text {th }}$ of the WT. There is residual islet mass found in the AGD mice that suggests other factors may act synergistically with amylin, or alternatively may play a role at a different stage in $\beta$-cell maturation.

We consider that the reduction in $\beta$-cell mass in AGD mice renders them more susceptible to the effects of toxins. Indeed, alloxan induced in these mice more severe diabetes[85]. Decreased $\beta$-cell mass was also found in transgenic, diabetic mice expressing human amylin[21,91] presumably due to the toxic effects of amyloid deposits and perhaps combined with a possible reduction in the activity of amylin as a growth factor due to amyloidogenesis.

Furthermore, in pancreatic islets, monomeric amylin may play a role in islet enlargement, an important concept linked to the progression towards overt diabetes. We (unpublished) and others[92] have noted enlarged islets in the fat but not thin Zucker rats, which ultimately became fibrotic. We propose that uncontrolled oversecretion of monomeric amylin in the local environment[93] promotes islet enlargement in this model and results in a prolonged local inflammatory response, which eventually leads to islet fibrosis (unpublished data). These rats have hyperamylinemia that may arise from a number of factors including elevated secretion. 
Indeed the genetic defect in these rats is an altered leptin receptor and leptin has been shown to suppress $\beta$-cell secretion.

Research aimed at the resolution of the role of amylin as a $\beta$-cell specific growth factor is a recent and important aspect of amylin biology. The reduction in the secretion of human amylin in the progression to overt diabetes may have consequences for the maintenance of $\beta$-cell mass. There is a $20-50 \%$ drop in $\beta$-cell mass in NIDDM pancreases as measured in autopsy tissues[21]. Therefore, it is postulated that treatment of subjects with or at risk of diabetes, with a monomeric amylin agonist may result in the preservation or even an increase in $\beta$-cell mass.

\section{BLOOD PRESSURE AND AMYLIN}

Amylin at physiological doses has been shown to stimulate renin activity in both rats[54] and man[94], and a modest pressor effect also has been noted[95,96]. This effect may be mediated by insulin-induced changes in renin release[97]. Furthermore, in rat models of renal hypertension, activation of renal amylin-binding sites could be correlated with blood pressure[4,5,56,98]. These high-affinity sites are located on proximal tubules[53,54,56]. More recently, amylin has been reported to induce relaxation of aortic rings[99], inhibit CCK-induced contraction of smooth muscle cells[100], and modulate pulmonary vascular tone[101]. Both the vasodilator effects of amylin on the mesenteric vasculature[102] and similar effects on coronary and basilar arteries are mediated by CGRP type 1 receptors[103,104]. However, in whole animal experiments with AGD mice, no altered blood flow rates in the whole pancreas, pancreatic islets, duodenum, ileum or colon were observed[105].

\section{AMYLIN HIGH-AFFINITY BINDING SITES AND PUTATIVE RECEPTORS}

\section{Calcitonin Receptors (CTR)/Receptor Activity Modifying Proteins (RAMP) Hypothesis}

It has been proposed that the affinity of the CTRs and CTR-like receptor (CRLR) may be modified by interactions with RAMPs[106,107]. Thus the pharmacological binding characteristics of the CTRs may be altered by coexpression of RAMPs 1, 2, or 3 as demonstrated with transfected cell lines. For instance, RAMPs 1 and 3 may combine with human CTR and result in a receptor with greater affinity for rat amylin[108,109].

\section{High-Affinity $\left[{ }^{125} \mathrm{I}\right]-$ Amylin Binding Sites in Kidney and CNS}

A number of anti-CTR antibodies have now been developed and characterized[17,110,111]. There is some discrepancy between the distribution of CTR ([17], Fig. 3A), which appears to be colocalized with RAMP-3 expression (Fig. 3B) in the distal tubules, collecting ducts, and ascending limbs of the loops of Henle, and high-affinity amylin binding sites[54] that have been found on the proximal tubules[53]. These data suggest that the renal amylin receptor is yet to be identified and characterized, and that it is most probably not related to CTR.

Similar studies[111] need to be performed in the CNS where high-affinity amylin binding sites have also been mapped[71,72]. Studies on the distribution of RAMP mRNA transcripts in the CNS have recently been reported[100,101]. An important issue is that further mapping studies should address concerns about the correlation of the locations of amylin binding sites with the 


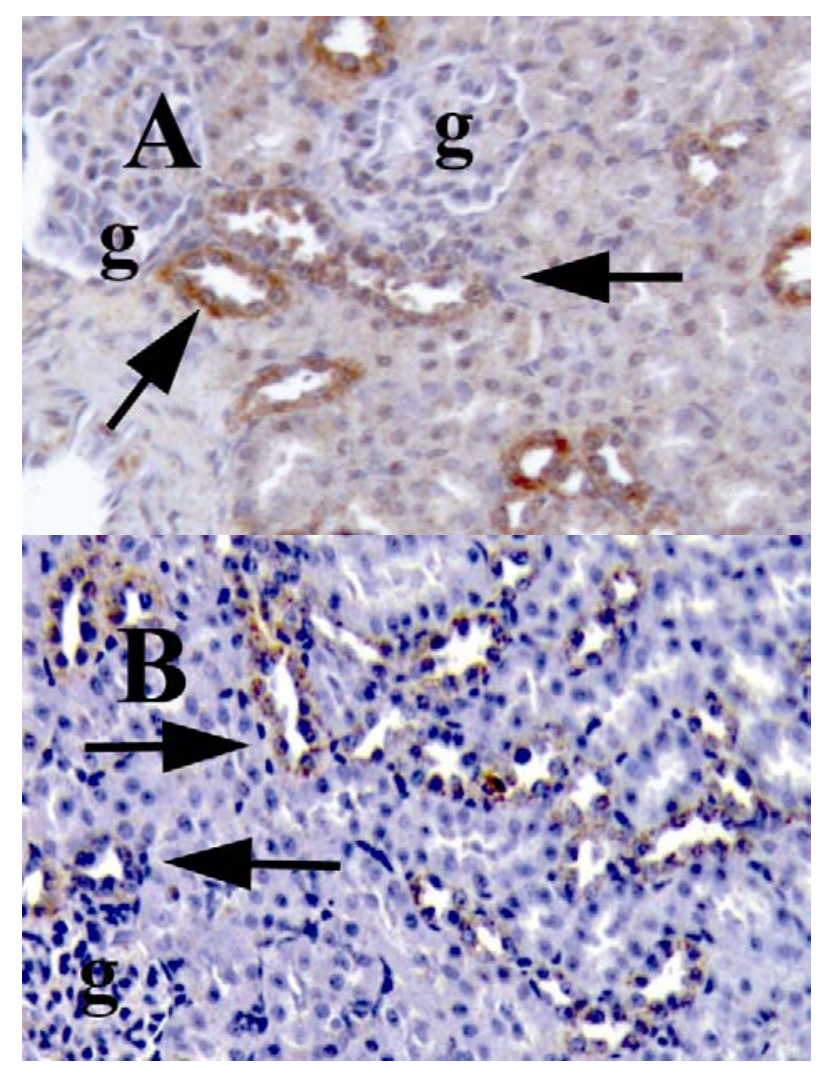

FIGURE 3. Immunohistochemical staining of rat PN30 kidney using (A) a monoclonal anti-CTR antibody[17] and (B) an anti-RAMP 3 antibody (Alpha Diagnostic Int).

expression of CTR isoforms and RAMP accessory proteins in the CNS. These important studies will aid in the identification of physiologically relevant amylin binding sites and receptor composition.

\section{CONCLUSIONS}

In this review we have concentrated on the recent research publications that address issues related to the biology of amylin. Of central importance to the etiology of diabetes, are the factors that contribute to the uncoupling of the regulation of $\beta$-cell-secreted products and atrophy of the $\beta$ cells themselves. The latter is dependent on the nature of amyloid deposits, the sensitivity of the $\beta$-cells, and the potency of amylin as a growth factor in this pathophysiological state. A study on the efficacy of an amylin nonpeptide agonist in this context would be useful to determine if the mass of $\beta$-cells can be conserved in a functional form.

Furthermore, in diabetic states little is known about expression from secondary sites of amylin biosynthesis discussed above and any significance that this might have for the etiology of diabetes and associated complications.

It is also debated whether amylin and/or prolonged activation of its receptors are central players in the maintenance of blood pressure and development of hypertension, respectively.

The question of the nature of amylin binding sites in the kidney, CNS, and elsewhere has yet to be resolved and the relation of these high-affinity binding sites to the CTR/RAMP hypothesis, which was derived from data generated from coexpression in cell lines. 
Amylin peptide antagonists have been used in a number of research projects to discern the functions of amylin in the periphery. Nevertheless, the final identification and verification of the physiological receptors for amylin should lead in the future to the characterization of amylin nonpeptide analogues, and is viewed as important for the future development of this field. Most importantly, these compounds may be useful to slow down the onset of diabetes and the treatment of related disorders such as diabetic nephropathy and hypertension.

\section{REFERENCES}

1. Rink, T.J., Beaumont, K., Koda, J., and Young, A. (1993) Structure and biology of amylin. Trends Pharmacol. Sci. 14, 113-118.

2. Cooper, G.J. (1994) Amylin compared with calcitonin gene-related peptide: structure, biology, and relevance to metabolic disease. Endocr. Rev. 15, 163-201.

3. Young, A.A., Rink, T.J., Vine, W., and Gedulin, B. (1994) Amylin and syndrome-X. Drug Dev. Res. 32, 9099.

4. Wookey, P., Cao, Z., and Cooper, M. (1998) Interaction of the renal amylin and renin-angiotensin systems in animal models of diabetes and hypertension. Miner. Electrolyte Metab. 24, 389-399.

5. Wookey, P.J. and Cooper, M.E. (1998) Amylin: physiological roles in the kidney and a hypothesis for its role in hypertension. Clin. Exp. Pharmacol. Physiol. 25, 653-660.

6. Gebre-Medhin, S., Olofsson, C., and Mulder, H. (2000) Islet amyloid polypeptide in the islets of Langerhans: friend or foe? Diabetologia 43, 687-695.

7. Cooper, G.J.S., Willis, A.C., Clark, A., Turner, R.C., Sim, R.B., and Reid, K.B.M. (1987) Purification and characterization of a peptide from amyloid rich pancreases of type 2 diabetic patients. Proc. Natl. Acad. Sci. U. S. A. 84, 8628-8632.

8. Westermark, P., Wernstedt, C., Wilander, E., Hayden, D.W., O'Brien, T.D., and Johnson, K.H. (1987) Amyloid fibrils in human insulinoma and islets of Langerhans of the diabetic cat are derived from neuropeptide - like protein also present in normal islet cells. Proc. Natl. Acad. Sci. U. S. A. 84, 3881-3885.

9. Morley, J.E. and Flood, J.F. (1991) Amylin decreases food intake in mice. Peptides 12, 865-869.

10. O'Brien, T. (2002) Pathogenesis of feline diabetes mellitus. Mol. Cell. Endocrinol. 197, 213-219.

11. Porte, D., Jr. (1991) Banting lecture 1990. Beta-cells in type II diabetes mellitus. Diabetes 40, 166-180.

12. Mulder, H., Lindh, A.C., Ekblad, E., Westermark, P., and Sundler, F. (1994) Islet amyloid polypeptide is expressed in endocrine cells of the gastric mucosa in the rat and mouse. Gastroenterology 107, 712-719.

13. Mulder, H., Ekelund, M., Ekblad, E., and Sundler, F. (1997) Islet amyloid polypeptide in the gut and pancreas: localization, ontogeny and gut motility effects. Peptides 18, 771-783.

14. Ferrier, G., Pierson, A., Jones, P., Bloom, S., Girgis, S., and Legon, S. (1989) Expression of rat amylin (IAPP/DAP) gene. J. Mol. Endocrinol. 3, R1-R4.

15. Fan, L., Westermark, G., Chan, S.J., and Steiner, D.F. (1994) Altered gene structure and tissue expression of islet amyloid polypeptide in the chicken. Mol. Endocrinol. 8, 713-721.

16. Mulder, H., Leckstrom, A., Uddman, R., Ekblad, E., Westermark, P., and Sundler, F. (1995) Islet amyloid polypeptide (amylin) is expressed in sensory neurons. J. Neurosci. 15, 7625-7632.

17. Tikellis, C., Xuereb, L., Casley, D., Brasier, G., Cooper, M.E., and Wookey, P.J. (2003) Calcitonin receptor isoforms expressed in the developing rat kidney. Kidney Int. 63, 416-426.

18. Wookey, P.J., Tikellis, C., Nobes, M., Casley, D., Cooper, M.E., and Darby, I.A. (1998) Amylin as a growth factor during foetal and postnatal development of the rat kidney. Kidney Int. 53, 25-30.

19. Sempoux, C., Guiot, Y., Dubois, D., Moulin, P., and Rahier, J. (2001) Human type 2 diabetes: morphological evidence for abnormal beta-cell function. Diabetes 50(Suppl. 1), S172-177.

20. Wang, F., Hull, R.L., Vidal, J., Cnop, M., and Kahn, S.E. (2001) Islet amyloid develops diffusely throughout the pancreas before becoming severe and replacing endocrine cells. Diabetes 50, 2514-2520.

21. Porte, D., Jr. and Kahn, S.E. (2001) beta-cell dysfunction and failure in type 2 diabetes: potential mechanisms. Diabetes 50(Suppl. 1), S160-163.

22. Mather, K., Paradisi, G., Leaming, R., et al. (2002) Role of amylin in insulin secretion and actions in humans: antagonist studies across the spectrum of insulin sensitivity. Diabetes-Metab. Res. Rev. 18, 118126.

23. Azriel, R. and Gazit, E. (2001) Analysis of the minimal amyloid-forming fragment of the islet amyloid polypeptide. An experimental support for the key role of the phenylalanine residue in amyloid formation. $J$. Biol. Chem. 276, 34156-34161.

24. Jaikaran, E.T. and Clark, A. (2001) Islet amyloid and type 2 diabetes: from molecular misfolding to islet pathophysiology. Biochim. Biophys. Acta 1537, 179-203. 
25. Jaikaran, E.T., Higham, C.E., Serpell, L.C., Zurdo, J., Gross, M., Clark, A., and Fraser, P.E. (2001) Identification of a novel human islet amyloid polypeptide beta-sheet domain and factors influencing fibrillogenesis. J. Mol. Biol. 308, 515-525.

26. Padrick, S.B. and Miranker, A.D. (2001) Islet amyloid polypeptide: identification of long-range contacts and local order on the fibrillogenesis pathway. J. Mol. Biol. 308, 783-794.

27. Mazor, Y., Gilead, S., Benhar, I., and Gazit, E. (2002) Identification and characterization of a novel molecular-recognition and self-assembly domain within islet amyloid polypeptide. J. Mol. Biol. 322, 10131024.

28. Nilsson, M., Driscoll, M., and Raleigh, D. (2002) Low levels of asparagines deamination can have a dramatic effect on aggregation of amyloidogenic peptides: implications for the study of amyloid formation. Protein Sci. 11, 342-349.

29. Sakagashira, S., Sanke, T., Hanabusa, T., Shimomura, H., Ohagi, S., Kumagaye, K.Y., Nakajima, K., and Nanjo, K. (1996) Missense mutation of amylin gene (S20G) in Japanese NIDDM patients. Diabetes 45, 1279-1281.

30. Seino, S. (2001) S20G mutation of the amylin gene is associated with Type II diabetes in Japanese. Study Group of Comprehensive Analysis of Genetic Factors in Diabetes Mellitus. Diabetologia 44, 906-909.

31. Lee, S.C., Hashim, Y., Li, J.K., Ko, G.T., Critchley, J.A., Cockram, C.S., and Chan, J.C. (2001) The islet amyloid polypeptide (amylin) gene S20G mutation in Chinese subjects: evidence for associations with type 2 diabetes and cholesterol levels. Clin. Endocrinol. (Oxf) 54, 541-546.

32. Ma, Z., Westermark, G.T., Sakagashira, S., Sanke, T., Gustavsson, A., Sakamoto, H., Engstrom, U., Nanjo, K., and Westermark, P. (2001) Enhanced in vitro production of amyloid-like fibrils from mutant (S20G) islet amyloid polypeptide. Amyloid 8, 242-249.

33. Park, K. and Verchere, C.B. (2001) Identification of a heparin binding domain in the N-terminal cleavage site of pro-islet amyloid polypeptide. Implications for islet amyloid formation. J. Biol. Chem. 276, 1661116616.

34. Wang, J., Xu, J., Finnerty, J., Furuta, M., Steiner, D.F., and Verchere, C.B. (2001) The prohormone convertase enzyme 2 (PC2) is essential for processing pro-islet amyloid polypeptide at the NH2-terminal cleavage site. Diabetes 50, 534-539.

35. Janson, J., Soeller, W.C., Roche, P.C., Nelson, R.T., Torchia, A.J., Kreutter, D.K., and Butler, P.C. (1996) Spontaneous diabetes mellitus in transgenic mice expressing human islet amyloid polypeptide. Proc. Natl. Acad. Sci. U. S. A. 93, 7283-7288.

36. Verchere, C.B., Dalessio, D.A., Palmiter, R.D., Weir, G.C., Bonnerweir, S., Baskin, D.G., and Kahn, S.E. (1996) Islet amyloid formation associated with hyperglycemia in transgenic mice with pancreatic beta cell expression of human islet amyloid polypeptide. Proc. Natl. Acad. Sci. U. S. A. 93, 3492-3496.

37. Tokuyama, T., Yagui, K., Yamaguchi, T., Huang, C.I., Kuramoto, N., Shimada, F., Miyazaki, J., Horie, H., Saito, Y., Makino, H., and Kanatsuka, A. (1997) Expression of human islet amyloid polypeptide/amylin impairs insulin secretion in mouse pancreatic beta cells. Metab. Clin. Exp. 46, 1044-1051.

38. Carty, M.D., Lillquist, J.S., Peshavaria, M., Stein, R., and Soeller, W.C. (1997) Identification of cis- and trans-active factors regulating human islet amyloid polypeptide gene expression in pancreatic beta-cells. $J$. Biol. Chem. 272, 11986-11993.

39. van Hulst, K.L., Born, W., Muff, R., Oosterwijk, C., Blankenstein, M.A., Lips, C.J., Fischer, J.A., and Hoppener, J.W. (1997) Biologically active human islet amyloid polypeptide/amylin in transgenic mice. Eur. J. Endocrinol. 136, 107-113.

40. MacArthur, D.L., de Koning, E.J., Verbeek, J.S., Morris, J.F., and Clark, A. (1999) Amyloid fibril formation is progressive and correlates with beta-cell secretion in transgenic mouse isolated islets. Diabetologia $\mathbf{4 2 ,}$ 1219-1227.

41. Westermark, G., Westermark, P., Eizirik, D.L., Hellerstrom, C., Fox, N., Steiner, D.F., and Andersson, A. (1999) Differences in amyloid deposition in islets of transgenic mice expressing human islet amyloid polypeptide versus human islets implanted into nude mice. Metabolism 48, 448-454.

42. Xue, B. and Zemel, M.B. (2001) Agouti signaling protein stimulates islet amyloid polypeptide (amylin) secretion in pancreatic beta-cells. Exp. Biol. Med. (Maywood) 226, 565-569.

43. Hull, R., Andrikopoulos, S., Verchere, C., et al. (2003) Increased dietary fat promotes islet amyloid formation and beta-cell secretory dysfunction in a transgenic mouse model of islet amyloid. Diabetes-Metab. Res. Rev. 52, 372-379.

44. Scrocchi, L., Chen, Y., Waschuk, S., et al. (2002) Design of peptide-based inhibitors of human islet amyloid polypeptide fibrillogenesis. J. Mol. Biol. 318, 697-706.

45. Novials, A., Rojas, I., Casamitjana, R., Usac, E.F., and Gomis, R. (2001) A novel mutation in islet amyloid polypeptide (IAPP) gene promoter is associated with Type II diabetes mellitus. Diabetologia 44, 1064-1065.

46. Brink, C., Chowdhury, K., and Gruss, P. (2001) Pax4 regulatory elements mediate beta cell specific expression in the pancreas. Mech. Dev. 100, 37-43.

47. Wang, M.W., Carlo, P., Rink, T.J., and Young, A.A. (1991) Amylin is more potent and more effective than glucagon in raising plasma glucose concentration in fasted, anesthetized rats. Biochem. Biophys. Res. Commun. 181, 1288-1293. 
48. Rushing, P.A., Hagan, M.M., Seeley, R.J., Lutz, T.A., D'Alessio, D.A., Air, E.L., and Woods, S.C. (2001) Inhibition of central amylin signaling increases food intake and body adiposity in rats. Endocrinology 142, 5035.

49. Silvestre, R.A., Rodriguez-Gallardo, J., Jodka, C., Parkes, D.G., Pittner, R.A., Young, A.A., and Marco, J. (2001) Selective amylin inhibition of the glucagon response to arginine is extrinsic to the pancreas. Am. J. Physiol. Endocrinol. Metab. 280, E443-449.

50. Ye, J.M., Lim-Fraser, M., Cooney, G.J., Cooper, G.J., Iglesias, M.A., Watson, D.G., Choong, B., and Kraegen, E.W. (2001) Evidence that amylin stimulates lipolysis in vivo: a possible mediator of induced insulin resistance. Am. J. Physiol. Endocrinol. Metab. 280, E562-569.

51. Cornish, J., Callon, K.E., King, A.R., Cooper, G.J., and Reid, I.R. (1998) Systemic administration of amylin increases bone mass, linear growth, and adiposity in adult male mice. Am. J. Physiol. 275, E694-699.

52. Hettiarachchi, M., Chalkley, S., Furler, S.M., Choong, Y.S., Heller, M., Cooper, G.J., and Kraegen, E.W. (1997) Rat amylin-(8-37) enhances insulin action and alters lipid metabolism in normal and insulin-resistant rats. Am. J. Physiol. 273, E859-867.

53. Harris, P.J., Cooper, M.E., Hiranyachattada, S., Berka, J.L., Kelly, D.J., Nobes, M., and Wookey, P.J. (1997) Amylin stimulates proximal tubular sodium transport and cell proliferation in the rat kidney. Am. J. Physiol. 272, F13-F21.

54. Wookey, P.J., Tikellis, C., Du, H.-C., Qin, H.-F., Sexton, P.M., and Cooper, M.E. (1996) Amylin binding in rat renal cortex, stimulation of adenylyl cyclase and activation of plasma renin. Am. J. Physiol. 270, F289F294.

55. Wookey, P. and Cooper, M. (2000) Amylin and hypertension: the status of the current debate. Diabetologia 43, 263.

56. Wookey, P.J., Cao, Z., van Geenen, R.C.I., Voskuil, M., Darby, I.A., Komers, R., and Cooper, M.E. (1997) Increased density of renal amylin binding sites in experimental hypertension. Hypertension 30, 455-460.

57. Lutz, T.A., Del Prete, E., and Scharrer, E. (1994) Reduction of food intake in rats by intraperitoneal injection of low doses of amylin. Physiol. Behav. 55, 891-895.

58. Reidiger, T., Rauch, M., and Schmid, H. (1999) Actions of amylin on subfornical organ neurons and on drinking behaviour in rats. Am. J. Physiol. 276, R514-R521.

59. Morley, J.E., Flood, J., and Silver, A.J. (1992) Effects of peripheral hormones on memory and ingestive behaviors. Psychoneuroendocrinology 17, 391-399.

60. Morley, J.E., Flood, J.F., Farr, S.A., Perry, H.J., Kaiser, F.E., and Morley, P.M.K. (1995) Effects of amylin on appetite regulation and memory. Can. J. Physiol. Pharmacol. 73, 1042-1046.

61. Clementi, G., Valerio, C., Emmi, I., Prato, A., and Drago, F. (1996) Behavioral effects of amylin injected intracerebroventricularly in the rat. Peptides 17, 589-591.

62. Young, A.A., Gedulin, B., Vine, W., Percy, A., and Rink, T.J. (1995) Gastric emptying is accelerated in diabetic bb rats and is slowed by subcutaneous injections of amylin. Diabetologia 38, 642-648.

63. Clementi, G., Caruso, A., Cutuli, V.M.C., Debernardis, E., Prato, A., and Amicoroxas, M. (1996) Amylin given by central or peripheral routes decreases gastric emptying and intestinal transit in the rat. Experientia 52, 677-679.

64. Gebre-Medhin, S., Mulder, H., Zhang, Y., Sundler, F., and Betsholtz, C. (1998) Reduced nociceptive behavior in islet amyloid polypeptide (amylin) knockout mice. Brain Res. Mol. Brain Res. 63, 180-183.

65. Schmid, H., Rauch, M., and Koch, J.(1998) Effect of calcitonin on activity of ANG II-responsive neurons in rat subfornical organ. Am. J. Physiol. 274, R1646-R1652.

66. Riediger, T., Schmid, H., Young, A., and Simon, E. (1999) Pharmacological characterization of amylinrelated peptides activating subfornical organ neurons. Brain Res. 837, 161-168.

67. Riediger, T., Schmid, H.A., Lutz, T., and Simon, E. (2001) Amylin potently activates AP neurons possibly via formation of the excitatory second messenger cGMP. Am. J. Physiol. Regul. Integr. Comp. Physiol. 281, R1833-1843.

68. Lutz, T., Senn, M., Althaus, J., Delprete, E., Ehrensperger, F., and Scharrer, E. (1998) Lesion of the area postrema nucleus of the solitary tract (AP/NTS) attenuates the anorectic effects of amylin and calcitonin gene-related peptide (CGRP) in rats. Peptides 19, 309-317.

69. Mollet, A., Lutz, T.A., Meier, S., Riediger, T., Rushing, P.A., and Scharrer, E. (2001) Histamine H1 receptors mediate the anorectic action of the pancreatic hormone amylin. Am. J. Physiol. Regul. Integr. Comp. Physiol. 281, R1442-1448.

70. Lutz, T.A., Tschudy, S., Mollet, A., Geary, N., and Scharrer, E. (2001) Dopamine D(2) receptors mediate amylin's acute satiety effect. Am. J. Physiol. Regul. Integr. Comp. Physiol. 280, R16971703.

71. Sexton, P.M., Paxinos, G., Kenney, M.A., Wookey, P.J., and Beaumont, K. (1994) In vitro autoradiographic localization of amylin binding sites in rat brain. Neuroscience 62, 553-567.

72. van Rossum, D., Menard, D.P., Fournier, A., St. Pierre, S., and Quirion, R. (1994) Autoradiographic distribution and receptor binding profile of $\left[{ }^{125} \mathrm{I}\right]$ Bolton Hunter-rat amylin binding sites in the rat brain. J. Pharmacol. Exp. Ther. 270, 779-787. 
73. Baldo, B.A. and Kelley, A.E. (2001) Amylin infusion into rat nucleus accumbens potently depresses motor activity and ingestive behavior. Am. J. Physiol. Regul. Integr. Comp. Physiol. 281, R12321242.

74. Morris, M.J. and Nguyen, T. (2001) Does neuropeptide Y contribute to the anorectic action of amylin? Peptides 22, 541-546.

75. Rindi, G., Terenghi, G., Westermark, G., Westermark, P., Moscoso, G., and Polak, J.M. (1991) Islet amyloid polypeptide in proliferating pancreatic B cells during development, hyperplasia, and neoplasia in humans and mice. Am. J. Pathol. 138, 1321-1334.

76. Wilson, M., Kalamaras, J., and German, M. (2002) Expression of IAPP and prohormone convertase 1/3 reveals a distinctive set of endocrine cells in the embryonic pancreas. Mech. Dev. 115, 171-176.

77. MacIntyre, I. (1989) Amylin-amide, bone conservation and pancreatic B-cells. Lancet ii, 1026-1027.

78. Zaidi, M., Datta, H.K., Bevis, P.J., Wimalawansa, S.J., and MacIntyre, I. (1990) Amylin-amide: a new boneconserving peptide from the pancreas. Exp. Physiol. 75, 529-536.

79. Zaidi, M., Shankar, V.S., Huang, C.L.H., Pazianas, M., and Bloom, S.R. (1993) Amylin in bone conservation- current evidence and hypothetical considerations. Trends Endocrinol. Metab. 4, 255-259.

80. Horcajada-Molteni, M.N., Chanteranne, B., Lebecque, P., Davicco, M.J., Coxam, V., Young, A., and Barlet, J.P. (2001) Amylin and bone metabolism in streptozotocin-induced diabetic rats. J. Bone Miner. Res. 16, 958-965.

81. Cornish, J., Callon, K.E., Cooper, G.J., and Reid, I.R. (1995) Amylin stimulates osteoblast proliferation and increases mineralised bone volume in adult mice. Biochem. Biophys. Res. Commun. 207, 133-139.

82. Cornish, J., Callon, K., Lin, C., Xiao, C., Mulvey, T., Coy, D., Cooper, G., and Reid, I. (1998) Dissociation of the effects of amylin on osteoblast proliferation and bone resorption. Am. J. Physiol. 274, E827-E833.

83. Cornish, J., Callon, K.E., Bava, U., Kamona, S.A., Cooper, G.J., and Reid, I.R. (2001) Effects of calcitonin, amylin, and calcitonin gene-related peptide on osteoclast development. Bone 29, 162-168.

84. Gebre-Medhin, S., Mulder, H., Pekny, M., Tornell, J., Sundler, F., Westermark, P., Ahren, B., and Betsholtz, C. (1996) Accelerated glucose elimination in IAPP/Amylin knockout mice. Diabetes 46(Suppl. 1), A56.

85. Mulder, H., Gebre-Medhin, S., Betsholtz, C., Sundler, F., and Ahren, B. (2000) Islet amyloid polypeptide (amylin)-deficient mice develop a more severe form of alloxan-induced diabetes. Am. J. Physiol. Endocrinol. Metab. 278, E684-691.

86. Wookey, P., Xuereb, L., Alcorn, D., Parkes, D., Devine, E., Young, A., and Cooper, M. (1999) Renal pathology associated with the postnatal mouse: the amylin gene-deletion model. J. Am. Soc. Nephrol. 10, 413A.

87. Gebre-Medhin, S., Mulder, H., Pekny, M., Westermark, G., Tornell, J., Westermark, P., Sundler, F., Ahren, B., and Betsholtz, C. (1998) Increased insulin secretion and glucose tolerance in mice lacking islet amyloid polypeptide (amylin). Biochem. Biophys. Res. Commun. 250, 271-277.

88. Lorenzo, A., Razzaboni, B., Weir, G.C., and Yankner, B.A. (1994) Pancreatic islet cell toxicity of amylin associated with type-2 diabetes mellitus. Nature 368, 756-760.

89. Karlsson, E. and Sandler, S. (2001) Islet amyloid polypeptide promotes beta-cell proliferation in neonatal rat pancreatic islets. Diabetologia 44, 1015-1018.

90. Villa, I., Rubinacci, A., Ravasi, F., Ferrara, A., and Guidobono, F. (1997) Effects of amylin on human osteoblast-like cells. Peptides 18, 537-540.

91. Soeller, W.C., Janson, J., Hart, S.E., Parker, J.C., Carty, M.D., Stevenson, R.W., Kreutter, D.K., and Butler, P.C. (1998) Islet amyloid-associated diabetes in obese A(vy)/a mice expressing human islet amyloid polypeptide. Diabetes $\mathbf{4 7}, 743-750$.

92. Janssen, S.W., Hermus, A.R., Lange, W.P., Knijnenburg, Q., van der Laak, J.A., Sweep, C.G., Martens, G.J., and Verhofstad, A.A. (2001) Progressive histopathological changes in pancreatic islets of Zucker Diabetic Fatty rats. Exp. Clin. Endocrinol. Diabetes 109, 273-282.

93. Inoue, K., Hiramatsu, S., Hisatomi, A., Umeda, F., and Nawata, H. (1993) Hypersecretion of amylin from the perfused pancreas of genetically obese (fa/fa) rats and its alteration with aging. Metabolism 42, 654-658.

94. Young, A.A., Vine, W., Carlo, P., Rink, T.J., Rumble, J., and Cooper, M.E. (1994) Amylin stimulation of renin activity in rats: a possible link between insulin resistance and hypertension. J. Hypertens. 12, S152.

95. Cooper, M.E., McNally, P.G., Phillips, P.A., and Johnston, C.I. (1995) Amylin stimulates plasma renin concentration in humans. Hypertension 26, 460-464.

96. Haynes, J., Hodgson, W., and Cooper, M.E. (1997) Rat amylin mediates a pressor effect in the anaesthetised rat. Diabetologia 40, 256-261.

97. Ikeda, T., Iwata, K., and Ochi, H. (2001) Effect of insulin, proinsulin, and amylin on renin release from perfused rat kidney. Metabolism 50, 763-766.

98. Cao, Z., Wookey, P., Wu, L., Voskuil, M., van Geenen, R., and Cooper, M. (1997) Renal amylin binding in normotensive and hypertensive rats: effects of angiotensin converting enzyme inhibition with perindopril. $J$. Hyper. 15, 1245-1252.

99. Luk'yantseva, G.V., Sergeev, I.Y., Kopylova, G.N., Samonina, G.E., and German, S.V. (2001) Effect of amylin on the tone of rat aorta ring preparation. Bull. Exp. Biol. Med. 132, 932-934. 
100. Ochiai, T., Chijiiwa, Y., Motomura, Y., Yasuda, O., Harada, N., and Nawata, H. (2001) Direct inhibitory effect of adrenomedullin, calcitonin gene-related peptide, calcitonin, and amylin on cholecystokinin-induced contraction of guinea-pig isolated caecal circular smooth muscle cells. Peptides 22, 909-914.

101. Golpon, H.A., Puechner, A., Welte, T., Wichert, P.V., and Feddersen, C.O. (2001) Vasorelaxant effect of glucagon-like peptide-(7-36)amide and amylin on the pulmonary circulation of the rat. Regul. Pept. 102, 8186.

102. Champion, H.C., Pierce, R.L., Bivalacqua, T.J., Murphy, W.A., Coy, D.H., and Kadowitz, P.J. (2001) Analysis of responses to hAmylin, hCGRP, and hADM in isolated resistance arteries from the mesenteric vascular bed of the rat. Peptides 22, 1427-1434.

103. Jansen-Olesen, I., Kaarill, L., and Edvinsson, L. (2001) Characterization of CGRP(1) receptors in the guinea pig basilar artery. Eur. J. Pharmacol. 414, 249-258.

104. Hasbak, P., Sams, A., Schifter, S., Longmore, J., and Edvinsson, L. (2001) CGRP receptors mediating CGRP-, adrenomedullin- and amylin-induced relaxation in porcine coronary arteries. Characterization with 'Compound 1' (WO98/11128), a non-peptide antagonist. Br. J. Pharmacol. 133, 1405-1413.

105. Carlsson, P., Karlsson, E., Mulder, H., and Gebre-Medhin, S. (2002) Unaltered pancreatic blood perfusion in islet polypeptide-deficient mice. Eur. J. Endocrinol. 146, 107-112.

106. McLatchie, L., Fraser, N., Main, M., Wise, A., Brown, J., Thompson, N., Solari, R., Lee, M., and Foord, S. (1998) RAMPs regulate the transport and ligand specificity of the calcitonin-receptor-like receptor. Nature 393, 333-339.

107. Poyner, D., Sexton, P., Marshall, I., et al. (2002) International Union of Pharmacology XXXII. The mammalian calcitonin gene-related peptides, adrenomedullin, amylin and calcitonin receptors. Pharmacol. Rev. 54, 233-246.

108. Christopoulos, G., Perry, K., Morfis, M., Tilakaratne, N., Gao, Y., Fraser, N., Main, M., Foord, S., and Sexton, P. (1999) Multiple amylin receptors arise from receptor activity-modifying protein interaction with the calcitonin receptor gene product. Mol. Pharmacol. 56, 235-242.

109. Muff, R., Buhlmann, N., Fischer, J.A., and Born, W. (1999) Amylin receptor is revealed following cotransfection of a calcitonin receptor with receptor activity modifying proteins-1or-3. Endocrinology 140, 2924-2927.

110. Kovacs, C., Chafe, L., Woodland, M., McDonald, K., Fudge, N., and Wookey, P. (2002) Calcitropic gene expression in the murine placenta suggests a role for the intraplacental yolk sac in maternal-fetal calcium exchange. Am. J. Physiol. 282, E721-E732.

111. Tolcos, M., Tikellis, C., Rees, s., Cooper, M., and Wookey, P. (2003) The localization of calcitonin receptor mRNA and protein in the developing central nervous system of rat. J. Compar. Neurol. 456, 29-38.

112. Oliver, K.R., Kane, S.A., Salvatore, C.A., Mallee, J.J., Kinsey, A.M., Koblan, K.S., Keyvan-Fouladi, N., Heavens, R.P., Wainwright, A., Jacobson, M., Dickerson, I.M., and Hill, R.G. (2001) Cloning, characterization and central nervous system distribution of receptor activity modifying proteins in the rat. Eur. J. Neurosci. 14, 618-628.

113. Ueda, T., Ugawa, S., Saishin, Y., and Shimada, S. (2001) Expression of receptor-activity modifying protein (RAMP) mRNAs in the mouse brain. Brain Res. Mol. Brain Res. 93, 36-45.

\section{This article should be referenced as follows:}

Wookey, P.J., Xuereb, L., Tikellis, C., and Cooper, M. E. (2003) Amylin in the periphery. TheScientificWorldJOURNAL 3, 163-175.

Handling Editor:

A. Buckle, Principal Editor for Protein Databases, Protein Degradation - domains of TheScientificWorldJOURNAL. 

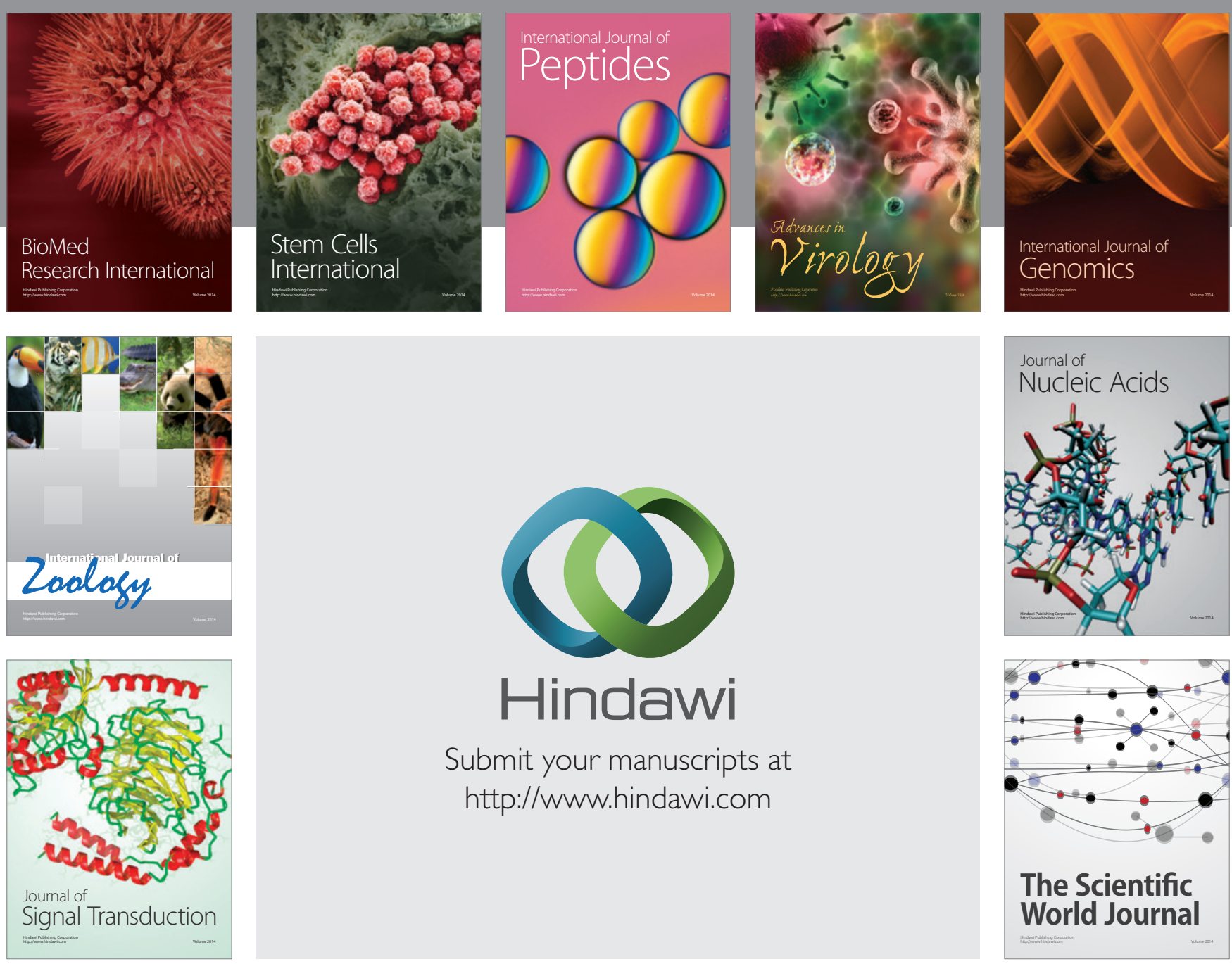

Submit your manuscripts at

http://www.hindawi.com
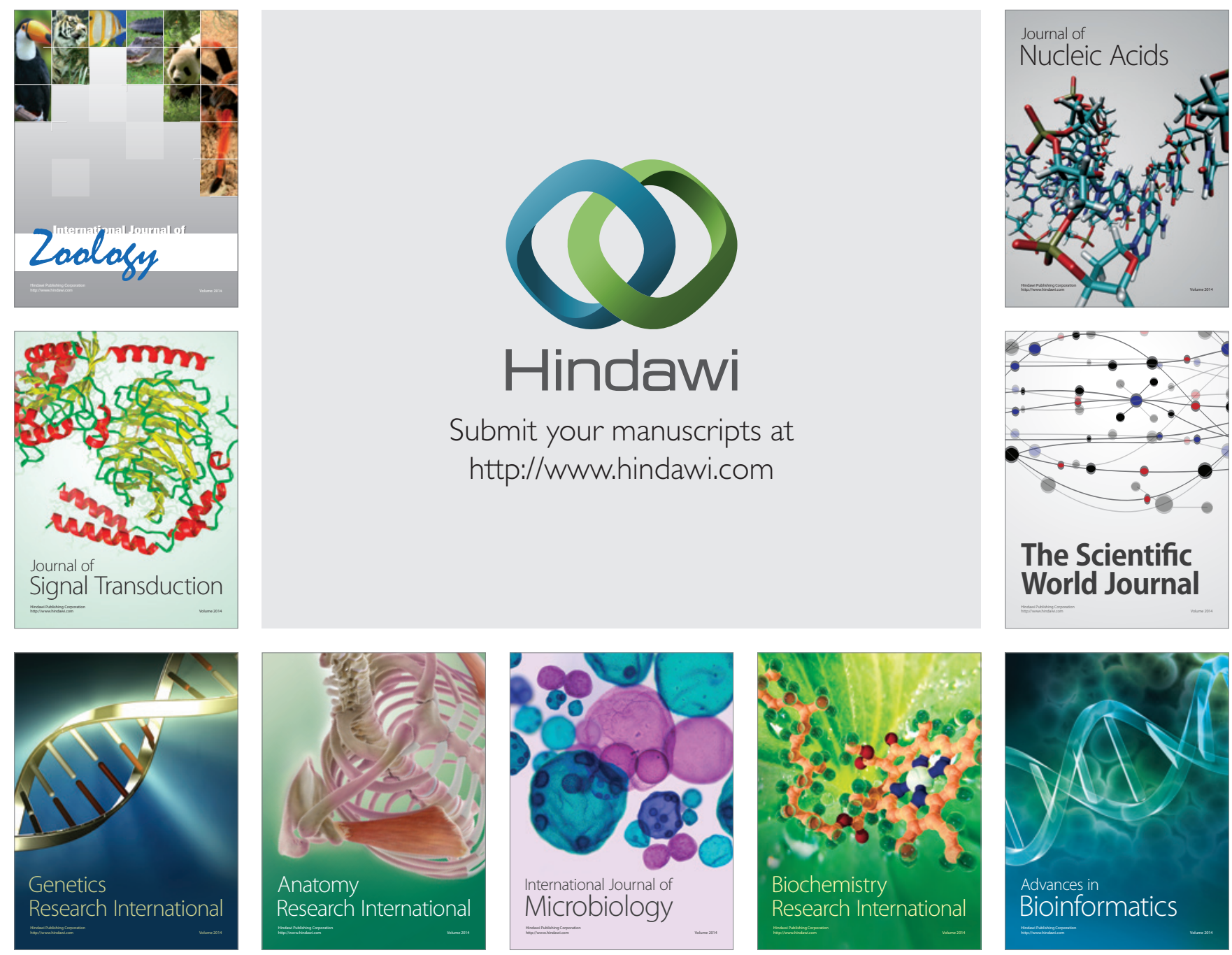

The Scientific World Journal
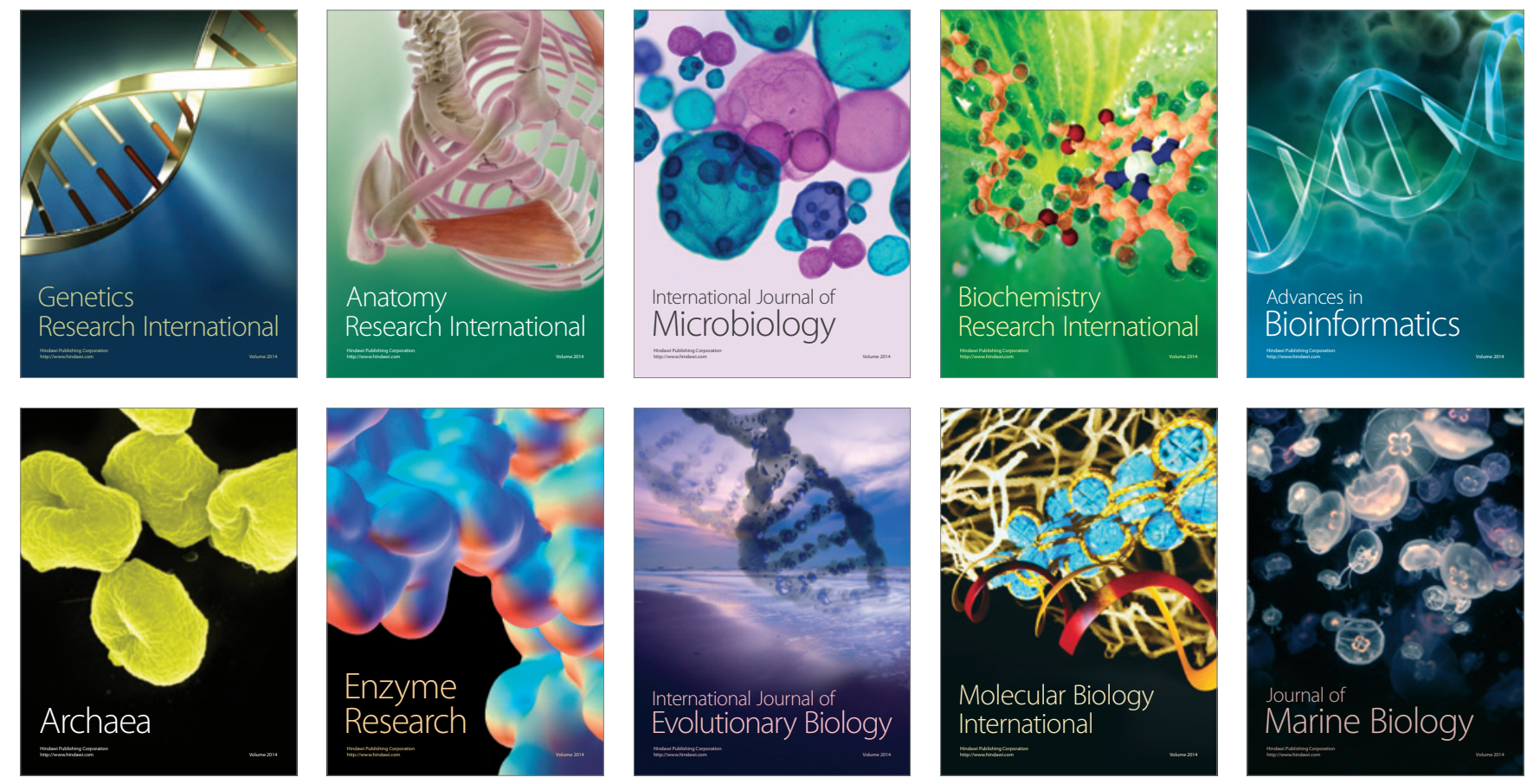